\title{
A Budapesti Magyar Királyi Állami Rendôrség \\ személyi állományának csoportjai és a rendőri őrség, illetve a detektívtestület tagjainak feladatkörei államosítástól államosításig
}

(The Royal Hungarian State Police in Budapest groups of personnel and members of the police guard and the detective team responsibilities from nationalization to nationalization)

\begin{abstract}
Absztrakt
A polgári magyar állam időszakában az első államosított rendőrség — igaz csupán ideiglenes jelleggel — a fövárosi rendörség volt, melyet Pest, Buda és Óbuda egyesítése kapcsán vontak a belügyi tárcán keresztül a kormány közvetlen irányítása alá. A budapesti rendőrséget 1881/XXI.tc.-kel államosították. A magyarországi városi rendőrségeket az 5 047/1919. (X. 1.) ME.r.-el államosították. Az államosítás során mintaként az egyébként példamutatóan müködő és kiválóm eredményeket létrehozó fövárosi rendőrséget tekintették követendő példának. A Budapesti Magyar Királyi Állami Rendőrség szervezetének és működésének a szabályzatait átvette az új országos hatáskörü Magyar Királyi Állami Rendőrség. Ezen okmányok váltak — az 1930-tól Magyar Királyi Rendőrségre átkeresztelt — magyar rendőri szervezet új szabályzatainak a kiinduló pontjává.
\end{abstract}

\section{Kulcsszavak}

Budapesti Magyar Királyi Állami Rendőrség ; Magyar Királyi Állami Rendőrség ; a rendőrség államosítása ; a fővárosi rendőrség személyi állománycsoportjai ; detektívtestület

\section{Abstract}

In the period of the bourgeois Hungarian state, the first nationalized police force - albeit only on a temporary basis - was the capital's police force, which was brought under the direct control of the government through the Ministry of the Interior in connection with the unification of Pest, Buda and Óbuda. The Budapest police were nationalized by 1881 / XXI.tc. The Hungarian city police officers were appointed in accordance with Decree 5 047/1919. (X. 1.) ME.r. During the nationalization, the otherwise exemplary and excellent results of the capital's police were considered as examples to follow. The regulations of the organization and operation of the Hungarian Royal Hungarian State Police have been taken over by the new Hungarian Royal Hungarian State Police. These documents became the starting point of the new regulations of the Hungarian police organization, renamed the Royal Hungarian Police from 1930.

\section{Keywords}

Budapest Royal Hungarian State Police ; Royal Hungarian State Police ; nationalization of the police ; capital police personnel groups ; detective body

$*$

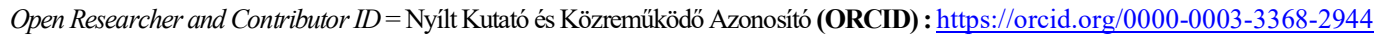

Institutional attachements = Szerző intézményi kötödései :

- Bertalan Szemere Scientific Society of History of Hungarian Law Enforcement = Szemere Bertalan Magyar Rendvédelem-történeti Tudományos Társaság

- Eötvös Loránd University Faculty of Law

= Eötvös Loránd Tudományegyetem Állam- és Jogtudományi Kar

- National University of Publik Service Faculty of Law Enforcement

= Nemzeti Közszolgálati Egyetem Rendészettudományi Kar @: paradi.jozsef@gmail.com

Date of registry $=$ Regisztrálás dátuma $: 2018$. V. 17. Date of acceptance $=$ elfogadás dátuma : 2018. VI. 17.

DOI : 10.31627/RTF.XXX.2020.5-609N.141-156P 
A fővárosi rendőrséget 1872-ben — Óbuda, Buda és Pest Budapestté egyesítése kapcsán ideiglenesen ${ }^{1}$, majd 1881-ben véglegesen ${ }^{2}$ államosították. A budapesti rendőrség hosszú ideig az egyetlen magyar rendőrség volt a dualizmus időszakában, amely a kormány közvetlen irányítása alatt állt. 1867 és 1919 között a Magyar Szent Korona alá tartozó területeken a fővárosi rendőrségen kívül csupán két állami rendőrség müködött, az 1906-ban felállított Magyar Királyi Határrendőrség ${ }^{3}$, valamint - a fiumei önkormányzati városi rendőrség és a fiumei határrendőr kapitányság összevonásával - 1916-ban létrehozott Fiumei Magyar Királyi Állami Rendőrség. ${ }^{4}$

A kiegyezést követően a rendőrhatósági jogköröket az önkormányzatokhoz telepítették. ${ }^{5}$ Ennek alapvetően két oka volt. Egyrészt a reformkorban a közigazgatás fejlesztéséről szóló elméleti vita részeként - amely a centralisták és a municipálisok között zajlott és a municipálisok javára dőlt el — az önkormányzati rendőrség ideája győzedelmeskedett. ${ }^{6}$ Másrészt pedig mivel — a magyarellenes HABSBURG-centralizáció elleni küzdelem bástyájának a szerepét a vármegyék töltötték be — az önkormányzatiság és annak részeként az önkormányzati kompetenciába tartozó rendvédelem a nemzeti szuverenitás visszaszorítására irányuló kezdeményezések elleni fellépés színterévé vált. Így pedig a közigazgatásban a nemzeti szuverenitásunk fontos elemévé erősödött az önkormányzati rendvédelem gondolatköre. Az önkormányzati rendörség és a szuverenitás témájának az egybefonódása tovább erösödött a neoabszolutizmus időszakában, amikor a magyar nemzet tagjai a gyakorlatban is kitapasztalhatták milyen az, ha egy idegen hatalom gyakorolja a saját szervezetei által a rend fenntartását. ${ }^{7}$

A dualizmus időszakának a kezdetén tehát a magyar rendvédelmet az önkormányzatiság jellemezte. Mivel azonban az önkormányzati rendőrségek nem váltották be a hozzájuk füzött reményeket, ezért fokozatosan és több lépcsőben — immár a magyar kormány közvetlen felügyelete alá tartozó - centralizált rendvédelmi struktúra alakult ki. Az 1881-ben létrehozott Magyar Királyi Csendőrség ilyen szervezet volt. ${ }^{\mathbf{4}}$ A magyarországi rendőrségek tekintetében pedig maguk a rendörtisztek — korabeli szóhasználat szerint a rendőrtisztviselők — kezdeményezték az államosítást. A közéletben kifejtett több évtizedes eredményes munka nyomán 1912-ben országgyülési döntés született arról, hogy a városi törvény módosítása kapcsán kidolgozásra kerüljön a magyarországi rendőrségek államosításának a témája. ${ }^{9}$ A Magyar Királyi Belügyminisztériumban külön részleget hoztak létre a téma kidolgozása céljából. A kidolgozó munkában a korabeli rendvédelmi szakemberek legjobbjai vettek részt. Az országgyülés elé 1914-ben került a javaslat, amelyet azonban a honatyák átdolgozás céljából visszaküldtek. A háború kitörése miatt pedig a törvényjavaslat többé nem került az országgyülés elé. ${ }^{10}$

1919-ben azonban a magyarországi tanácsköztársaság bukása után rövid időn belül miniszterelnöki rendelettel államosították a magyar városi rendőrségeket 1919. X. 1-én. ${ }^{11}$

Ennek az új — immár a magyarországi városok területére kiterjedő — Magyar Királyi Állami Rendőrségnek vált a részévé a fóvárosi rendőrség. A városi rendőrségek új szervezetbe tömörítését és a belügyi tárcán keresztül a kormány közvetlen irányítása alá vonását nevezték a kortársak a rendőrség államosításának. Ez a kifejezés helytálló volt abban a tekintetben is, hogy a rendőrség költségvetése a kormány költségvetésének a részévé vált, a testület tagjai pedig az önkormányzati státuszból állami státuszba kerültek. A magyarországi rendőrségek államosításával a budapesti rendőrség viszonyait tették általánossá az immár országos új rendőri szervezet valamennyi kapitányságánál. Ennek részeként a testület szervezeti felépítése, a személyi állománycsoportok, a képesítési és a fizetési rendszer, az egyenruha és a rendfokozati rendszer stb. a budapesti minta alapján vált egységessé. Az átállás során tehát — amely 1919 októberétől 1921 augusztusáig tartott — a Budapesti Magyar Királyi Állami Rendőrség humán viszonyait tették általánossá országszerte. Ez a humán viszonyrendszer 1872-től 1918-ig formálódott ugyan, zömében azonban a XIX. század végére már kialakult. ${ }^{12}$

A magyarországi rendőrségek tehát - legalább is a városi rendőrségek — eggyé váltak. Ez az egységesülés a polgári fegyveres örtestületek körülményeinek megfelelően ment végbe. A polgári magyar állam időszakában ugyanis kétféle rendvédelmi testülettípust különböztettek meg, nevezetesen a katonailag szervezett fegyveres örtestületet és a polgári fegyveres örtestületet. Katonailag szervezett fegyveres örtestületnek azokat a fegyveres szervezeteket nevezték, amelyek személyi állományának a tagjai személyükben katonának minősültek függetlenül attól, hogy az a testület, amelyben szolgálatot teljesítettek mely tárca irányítása alatt állt. A testületen belüli függelmi viszonyok pedig katonaiak voltak. Ezen testületek tagjai katonai rendfokozatot viseltek, őket a katonákra általában vonatkozó jogosultságok megillették, illetve kötelezettségek terhelték. Ezzel szemben a polgári fegyveres örtestületeken belüli függelmi viszonyok hivatalnokiak voltak. Ezen testületek személyi állomá- 
nyainak a tagjait nem a katonákra általában vonatkozó, hanem az állami tisztviselői jogviszonyból fakadó jogosultságok illették meg, illetve kötelezettségek terhelték. A polgári fegyveres őrtestületek személyi állományának a tagjai annak a tárcának a kompetenciájába tartoztak, amely minisztérium a testület irányítását végezte. Mivel a polgári fegyveres örtestületek tagjai nem katonának, hanem hivatalnoknak minősültek, ezért katonai rendfokozatot sem viselhettek. A polgári fegyveres örtestületek tagjai testületi rendfokozatot hordtak, amely az elnevezésében és formai megnevezésében is eltért a katonai rendfokozati rendszertől. ${ }^{13}$

A dualizmus időszakában a Magyar Szent Korona alá tartozó területeken müködő országos hatáskörü és 10 évnél hosszabb ideig müködő katonailag szervezett rendvédelmi fegyveres örtestület volt a Magyar Királyi Csendőrség, a Magyar Királyi Nemesi Testőrség, a Magyar Királyi Darabont Testőrség, a Magyar Királyi Koronaőrség és a Magyar Királyi Képviselőházi Örség. Ezen időszakban a történelmi Magyarország területén müködő valamennyi rendörség — állami és önkormányzati — a Magyar Királyi Pénzügyőrség és a fegyőr testület polgári fegyveres örtestületek voltak. ${ }^{14}$

A Budapesti Magyar Királyi Állami Rendőrség személyi állománya két fő csoportra osztható, nevezetesen a rendőrtisztviselők (napjaink fogalmai szerinti rendőrtisztek) és a legénység, azaz az altisztek csoportjára. Ez utóbbi - a két világháború közötti időszakban és valamennyi rendvédelmi testületre kiterjedően - a Magyar Királyi Honvédség altiszti karának a jellegével bírt. Emellett a testület rendelkezett úgynevezett szolga státuszokkal is, akik a testület müködéséhez szükséges egyszerü fizikai feladatokat láttak el, mint például a takarítás, fütés stb. ${ }^{15}$

A tiszti kar a felügyelőkből, fogalmazókból és tanácsosokból állt. A felügyelői rendfokozatok eléréséhez az állami iskolai végzettségszint az érettségi, a fogalmazói rangcsoportba pedig az állami iskolai követelmény az egyetemi diploma volt. A tanácsosi rangcsoportba általában a fogalmazók köréből kerültek ki a jelöltek, így a diploma mint előfeltétel már adott volt. A legénység, azaz az altiszti kar esetében az állami iskolai végzettségbeli követelményt az elemi iskola képezte. Az állami iskolai végzettségre - mint általános közismereti alapra - épültek rá a felügyelői, fogalmazói és tanácsosi rangcsoportba való belépés feltételeként a különböző rendőri szaktanfolyamok eredményes elvégzésének a követelménye. ${ }^{\mathbf{1 6}}$

A tiszti személyzet különböző típusú beosztásokat látott el. Ennek megfelelően tért el az adott szinten belül az elöírt állami iskolai végzettség — például orvosi diploma, jogi diploma stb. — tartalma, valamint az elvégzendő rendőri szaktanfolyam ismeretanyaga. Beosztástípusok voltak a rendőr oktatók (legénység oktatói), díjnokok (őket általában meghatározott időre, vagy kijelölt feladat ellátására foglalkoztatták többnyire valamilyen adminisztratív teendő ellátására), kezelők (a mai ügyviteli irodák elődei), írnokok (jelentések, jegyzőkönyvek stb. tisztázott másolatait készítették, mivel még írógép sem volt nem is beszélve a számítógépről), ellenőrök (az őrszolgálati személyzet — napjaink terminológiája szerinti közrendvédelmi állomány — szolgálatellátását ellenőrizték), házgondnokok, pénztárnokok, orvosok, főkapitányi titkárok, hivatalfőnökök (például bejelentési hivatal), hivatalok munkatársai, kapitányok, 1885-ig biztosok, majd detektívek.

A rendőrlegénység két csoportból állt, a gyalogos és a lovas rendőrökből.

A budapesti rendőr-főkapitányt az uralkodó, míg a főkapitányságon szolgálatot teljesítő többi vezető tisztséget betöltő személyt a belügyminiszter javaslatára a miniszterelnök, a rendőri legénységet pedig — próbaidő után — a fökapitány javaslatára a belügyminiszter nevezte ki. A szolgákat pedig a fökapitány fogadta fel.

A fővárosi rendőri őrség legénységi állományába való felvétel előfeltétele volt a magyar állampolgárság, 33-40 év közötti életkor, a tökéletes egészség és erős testalkat, a fedhetetlen előélet, a magyar nyelv bírása szóban és írásban, a haderőnél altiszti rangban teljesített szolgálat. A felvétel során elsőbbséget élveztek az előírtnál magasabb iskolai végzettségüek, az idegen nyelvismerettel is rendelkezők - elsősorban a történelmi Magyarországon beszélt nyelveket illetően — a csendőrségtől önként kilépett (nem elbocsájtott), a főváros helyi viszonyait jól ismerők.

A testülethez való felvétel tekintetében elsősorban a szolgai állások betöltését illetően a kiszolgált altisztek alkalmazásáról szóló törvényben foglaltak voltak érvényben a fővárosi rendőrségre vonatkozóan is. ${ }^{\mathbf{1 8}}$

A Magyar Királyságban az állami tisztviselők és hasonló állásúak számára a képesítési szintjükhöz igazodóan 11 fizetési osztályt állapítottak meg. Ezt egészítette ki a 12. fizetési osztály a gyakornokok számára. Magasabb fizetési osztályokba úgy kerülhettek a hivatalnokok, ha az azokhoz előírt képesítési követelményekben meghatározott állami iskolai végzettség birtokába kerültek és az elöírt szakmai tanfolyamot is eredményesen elvégezték. Ugyanez a rendszer volt érvényben a 
Budapesti Magyar Királyi Állami Rendőrség személyi állománya számára is azzal a különbséggel, hogy a szaktanfolyamok tematikája rendőri témájú volt. ${ }^{19}$

A budapesti rendőrség személyi állományával szemben olyan speciális elvárásokat is támasztottak, amelyek a testület jellegéből fakadtak és a magyar közigazgatásban foglalkoztatottak tekintetében általában nem volt követelmény. Ennek értelmében a testületnél foglalkoztatottak nem lehettek a budapesti esküdtszék tagjai, továbbá a településen müködő üzletben sem vehettek részt, valamint a testületi tagokkal egy háztartásban élö hozzátartozók rendőri felügyelet alatt álló üzletnek birtokosai, vagy haszonélvezői nem lehettek. Ezt a tiltást — immár az államosított Magyar Királyi Állami Rendőrség teljes személyi állományára kiterjedően - 1920-ban megerősítették. A rendőr semmiféle ajándékot nem fogadhatott el, amely a szolgálatteljesítésre hatást gyakorolhatott. A rendőrnek politikai szervezetbe belépése, azoknak a rendezvényein megjelenése tiltott volt, más társadalmi szervezetekbe azonban a szolgálati elöljárója beleegyezésével beléphetett, munkájában részt vehetett. A testület tagjai magáncélból kétes hírü szórakozóhelyeket nem látogathattak, kétes hírü személyekkel nem barátkozhattak, házasságon kívül idegen nővel közös háztartásban nem élhettek, beadványok szerkesztésére, illetve ilyen iratok támogatására vállalkozniuk tilos volt. A rendőr köteles volt nősülését, lakcímét, megbetegedését haladéktalanul jelenteni.

A rendőri szolgálat azonban nehezebb és veszélyesebb volt, mint a közigazgatás más területein végzett munka. Ezt különböző pótlékok formájában igyekeztek kompenzálni. Az altiszti kar körében $5,10,15$, illetve 20 éve szolgálók a szolgálati idejüktől függő mértékü szolgálati pótlékban részesültek. Ezek a szolgálati pótlékok beszámítottak a nyugdíjak összegébe, valamint az özvegyi ellátásba és a gyermekek ellátási díjába is. Egyébként a testület teljes személyi állományára szinte ugyanazon nyugdíj, illetve özvegyi és árvaellátási szabályok vonatkoztak, mint amelyek az állam által foglalkoztatottakra általában érvényesek voltak. ${ }^{20}$

Azon újoncokat véglegesítették a testületnél, akik a próbaidejük alatt az elvárásoknak megfelelően látták el szolgálatukat. A véglegesítéskor a próbaidőt is a szolgálati időhöz kapcsolták. A fegyveres szolgálatot ellátók körében azonban így is viszonylag nagy volt a száma azoknak, akik a nyugdíjba vonulásukat megelózően vagy azt követő néhány éven belül meghaltak. Ezért a fegyveres szolgálatot teljesítők esetében a szolgálati idő első öt évét duplán számították. Ebből fakadóan pedig a civil állami alkalmazottakhoz képest öt évvel korábban mehettek nyugdíjba oly módon, hogy a szolgálati idejük, illetve az azt is tükröző nyugdíjuk nem volt kevesebb mint a nyugdíjba vonuló civil állami alkalmazottaké. ${ }^{21}$

A fegyveres szolgálatellátásból fakadó kedvezménynek tekinthető továbbá, hogy a szolgálatteljesítés közben elszenvedett sebesülésekböl fakadó szolgálatképtelenség bekövetkeztekor a rendör szolgálati éveihez 10 évet hozzászámítottak. Ez jelentős kedvezménynek tekinthető, hiszen az állami alkalmazottak 10 évi szolgálat után nyugdíjként fizetésük $40 \%$-ra voltak jogosultak, amely minden további leszolgált évvel $2 \%$-al nőtt. İgy tehát 40 évi szolgálat után - amely után kötelező volt mindenkinek nyugdíjba vonulnia - a fizetésük $100 \%$-át kapták nyugdíjként az állami alkalmazottak. A másik fontos szabály pedig az volt, hogy 65 éves kora után senki sem maradhatott állami szolgálatban függetlenül attól, hogy a szolgálati évei után járó fizetése hány százalékára volt jogosult nyugdíjként. ${ }^{22}$

Lehetőség nyílt arra is, hogy a budapesti fökapitány, vagy távollétében a helyettese úgynevezett pótrendöröket foglalkoztasson. A pótrendőrök foglalkoztatási költségeit azoknak kellett állniuk, akik — általában értékes árut tartó üzletek tulajdonosai - ilyen támogatást kértek. A pótrendörök azon teendők végrehajtására voltak igénybe vehetők, amely feladat teljesítése érdekében kérték az érintettek a foglalkoztatásukat. A pótrendőrök ruházata és felszerelése a többi rendőréhez hasonló volt, illetve az intézkedési jogosultságaik megegyeztek a többi rendőrével. A pótrendöröket meghatározott időre külön szerződéssel vették fel. Munkaviszonyuk a foglalkoztatásukat kezdeményezők igényének a visszavonását követő három hónap elteltével szünt meg. Müködésük azonban a tevékenységüket kérelmezők visszavonásakor azonnal beszüntetésre került, amikor az egyenruhájukat és felszerelésüket is bevonták. ${ }^{23}$

A vizsgált testület müködése tekintetében nyilvánvalóan a szüken vett rendőri teendőket ellátó egyenruhás és civilruhás rendőri beosztások feladatköre a leglényegesebb. Természetesen az iratkezelö, gazdasági hivatalok munkatársai és az orvosok munkája is fontos, sőt nélkülözhetetlen volt, hiszen másként ezen státuszokat nem alakították volna ki. A szervezeten belül azonban voltak olyan beosztás típusok is, amelyek léte és müködtetése közvetlenül meghatározta a testület tevékenységét. Lényegében ezek a feladatkörök határozták meg a testület jellegét. A vezetői beosztások körében kimagasló szerepet töltött be a fökapitányi és helyettesei, valamint a rendőrkapitányi beosztások. 
A budapesti rendörfökapitány — akinek a tevékenységét a fökapitányi hivatal volt hivatva támogatni - hatásköre kiterjedt:

- a fontosabb bünügyekre;

- házkutatást és személyi motozást bírói ítélet nélkül is elrendelhetett törvényben rögzített esetekben;

- az altiszti karnak az esküjét a főkapitány előtt kellett letennie;

- a fökapitány hatáskörébe tartozott a rendőr tanfolyamra jelentkezők felvétele, majd az eredményes vizsga és próbaszolgálat után a véglegesítés a miniszter hozzájárulásával, továbbá a szolgák felfogadása;

- a pótrendörök felvétele és eskü alá vonása ${ }^{24}$;

- a fegyelmi eljárásokban való részvétel a tiszti személyzet tekintetében első fokon, az altisztek tekintetében rang és hivatalvesztés tekintetében másodfokon. ${ }^{25}$

Ezeket a hatásköröket a fökapitány helyettesek csak a fökapitány távollétében gyakorolhatták abban az esetben, ha a belügyminiszter őket a helyettesítéssel megbízta. Voltak azonban olyan hatáskörök is, amelyeket a fövárosi rendőrség központi szervezetében kellett ugyan gyakorolni, azonban azokat már a fökapitány által megbízott testületi tagok is megvalósíthatták, ide tartoztak:

- államrendőri ügyek (mai fogalmaink szerinti nemzetbiztonsági ügyek);

- gyilkosságok, rablások, nagyértékü betörések;

- mindazon ügyek, amelyekre nézve a főváros egyes területére kiterjedő egyöntetü eljárás foganatosítása szükséges volt;

- népgyülési ügyek;

- színházak, nyilvános előadások és mulattságok ügyei;

- közigazgatási bizottságban a testület képviselete;

- pénzbüntetések;

- toloncügy;

- bordélyügy;

- útlevélügy;

- bérkocsik ügyei;

- vasúti és gőzhajózási müszaki ügyek;

- sajtótermékek ügyei;

- külföldi rendőri hatóságokkal való levelezés;

- a rendőrök személyi ügyei;

- a fökapitányi hivatalba beosztottak személyi munkaköreinek a megállapítása;

- gazdászati és iratkezelési ügyek felügyelete;

- az éves költségvetés;

- panaszügyek. $^{26}$

A kerületi rendörkapitányságok a fökapitányság alárendeltségébe tartoztak. Élükön a rendörkapitányok álltak, akik a rendőr-főkapitány irányítása alá tartoztak. A kapitányok tevékenységét a kapitányi hivatalok támogatták. A kapitányok a kapitányságuk müködési területén felelősek voltak a törvények és rendeletek, valamint a budapesti törvényhatósági szabályrendeletek és a rendörfőkapitány rendelkezései szerint a jogszabályok ellen vétők felderítése és eljárás alá vonása. A rendőrkapitányságok a nyilvános helyek felett közvetlen felügyeletet gyakoroltak. A kapitányok kötelesek voltak a nevezetes eseményekről a főkapitányságot azonnal értesíteni, a közrendészeti hiányosságokra pedig a fökapitány figyelmét felhívni. A kapitányságokon tiszti ügyeletet kellett tartani a hét minden napján. A kapitánysági hivatalok a főkapitány által jóváhagyott müködési szabályzat szerint tevékenykedtek. ${ }^{27}$

A föparancsnok alá tartoztak a rendőr altisztek. A föparancsnok a fökapitány közvetlen beosztottja volt, a fökapitányi hivatal (elnöki osztályának) munkatársaként őrségi ügyekben az előadói tisztet látta el. Hozzá tartozott az őrszolgálati állomány szolgálati beosztása. Feladatát alkotta az őrszolgálatot ellátó rendőrök ellenőrzése, az őrszobák szemlézése, az őrszolgálatot teljesítő rendőrök továbbképzésének az irányítása, az őrszolgálat ellátásához szükséges felszerelés biztosítása és tárolási feltételeinek a megteremtése, valamint a fenntartása. Hozzá tartozott továbbá a lovas rendőröknek a lovakkal kapcsolatos — utánpótlás, képzés, tartás stb. — összes ügye is. ${ }^{28}$

A föfelügyelö a föparancsok helyettese volt. Feladatát alkotta a föparancsnok tevékenységének támogatása. 
Az osztályparancsnokok a rendőr legénység területi elv szerinti elöljárói voltak. Hatáskörük általában egy-egy fővárosi kerületben a rendőri örszolgálat irányítására terjedt ki. Az osztályparancsnokok intézték:

- az osztályukhoz tartozó rendőri legénység személyi ügyeit;

- gyakorolták a fegyelmi hatalmat;

- ellenőrizték a rendőr őrszobákat;

- felügyelték a rendőr altisztek oktatását;

- rendezték a hatáskörükbe tartozó gazdasági ügyeket.

Az oktató felügyelők végezték az őrszolgálati állomány képzését. Feladatukat alkotta a szolgálat ellátása során gyakran előforduló helyzetek a helyes reagálására való felkészítés, a fegyverhasználat szabályozásának gyakorlatias helyzetekre való alkalmazásának képzése, a gyakran előforduló feladatok - elővezetés, bekísérés, bilincselés stb. — gyakoroltatása.

A számvivők az őrszolgálati teendők ellátásához szükséges tárgyak nyilvántartását, raktározását végezték.

A gyalogos felügyelökre hárult a gyalogos rendőrök szolgálatellátásának ellenőrzése éjjel és nappal.

A rendör lovasok számára külön felügyelöket alkalmaztak, akiknek a feladatköre ugyan megegyezett a gyalogos rendör felügyelökével, azonban azon túlmenően hozzájuk tartozott minden, ami a lovakkal állt összefüggésben.

Az állatorvos is a budapesti rendőrség személyi állományához tartozott, aki a lovak egészségéért felelt.

Azt a fajta rendőri szolgálatot, amit napjainkban a közrendvédelmi szolgálatnak neveznek a gyalogos-, és a lovas rendőr altisztek végezték. ${ }^{29}$

A rendör altisztekkel (más néven rendőr legénységgel) találkozott a fővárosi lakosság a leggyakrabban. Velük szemben elvárás volt az udvarias, de határozott és egyértelmü fellépés. A felkészítésük tananyaga is úgy került kialakításra, hogy abban helyet kapjanak a bünözők üldözésének metodikai szabályai mellett a lakosság közvetlen segítését lehetővé tévő ismeretek is, mint például az elsősegély nyújtás, az útba igazításhoz szükséges helyismeret stb. A fôváros belterületén — ahol a rendőri őrség döntő többsége teljesített szolgálatot — úgynevezett örszobai és posztos rendszerben végezték feladatukat a rendőrök. E rendszerben 24 órás váltással vezényelték a rendőröket örszobai szolgálatra. Onnan pedig négy órás váltással kerültek ki a közterületek kulcspozícióihoz telepített posztokra a rendőrök. Alapelv volt, hogy lehetőleg egy rendőr mindig ugyanarra a posztra kerüljön, hogy a helyi lakossággal közvetlen kapcsolatba kerülve értékes helyismeretre tehessen szert. A posztokat úgy alakították ki, hogy azok látó- és hallótávolságban legyenek egymástól. Az örszolgálati személyzet a városban fegyverként döntően csupán a kardját használhatta. Pisztolyt csak végszükség esetén saját vagy mások testi épsége védelmében használhatott. A lőfegyver használatot kerülniük kellett, mivel a zsúfolt városban ezt rendkívül balesetveszélyesnek tartották. ${ }^{30}$

A dualizmuskori viszonyok között a budapesti rendőrség felfegyverzettsége átlagon felüli volt annak ellenére, hogy a rendőr legénység kezdetben csak hidegfegyverrel (karddal) és lőfegyverként pisztollyal rendelkezett, mivel öket kezdetben karabéllyal nem látták el. Később azonban már a karabélyt is rendszeresítették a számukra azt viszont csak rendkívüli helyzetekben osztották ki a szolgálati teendőket ellátó rendőrök számára. A budapesti rendőr legénység egységes fegyverzettel rendelkezett, mivel az állami rendőrségek számára az állam rendszeresítette a szolgálati fegyvereket. Ezzel szemben az önkormányzati rendőrségek többségénél a rendőrök saját maguk szerezték be a fegyvereiket. Ebből adódóan pedig ezen rendőrségeknél jóformán annyiféle fegyvert használtak, ahány rendőr szolgálatot teljesített a testületnél.

Az altiszti kar irányítását, ellenőrzését, továbbképzését tehát több szintü és szakterületi irányultságú rendőr személyzet látta el. Erre szükség volt, hiszen az altiszti kar alkotta a budapesti rendőrség legnagyobb létszámú részét. Az utolsó békeévben a fővárosi rendőrség őrszemélyzeti létszáma 2073 fỏ volt. A kommün bukása után — azaz a testületnek az újonnan létrehozott Magyar Királyi Állami Rendőrségnek a kötelékébe vonását követően — pedig 3386 föt számlált a fővárosi rendőrség őrszemélyzete. ${ }^{31}$ Népszámlálást a Magyar Királyságban az érintett időszakban 1910-ben és 1920-ban hajtottak végre. 1910-ben Budapest területe 193,99 km , lakosainak száma 880371 fö volt, azaz 4538 lakos esett egy km-re, míg 1920-ban változatlan összterület mellett 928996 fö volt budapesti illetőségü, azaz 4789 fő jutott egy $\mathrm{km}^{\square}$-re a főváros területén. ${ }^{32}$ Így tehát 1910-ben 10,7 fö rendőr jutott egy $\mathrm{km}^{\square}$-re és egy rendörre 424,68 fö lakos esett, míg 1920-ban 17,45 fö rendör jutott egy km ${ }^{\square}$-re, egy rendőrre pedig 274,36 fő lakos esett. 
A rendőr legénység természetesen nem azonos sürüséggel teljesített szolgálatot a város kül- és belterületén. Budapest külterületén a rendőri szolgálatot járőrözéssel — korabeli terminológia szerint „őjáratokkal” — látták el. Az őrjáratok két, vagy több fősek voltak.

Akár posztos őrség, akár ôrjárati formában látta el a rendőr legénység a szolgálatát, a kivonulásukat megelőzően általában az örszoba parancsnoka által tartott eligazításban részesültek, bevonuláskor pedig szóbeli jelentéstételi kötelezettségük volt.

A rendőri őrség egy részét azonban nem vezényelték őrjáratba, vagy őrszemszolgálatba, hanem szükség esetén bevethető tartalékként alkalmazták. A kerületi kapitányságok és a főkapitányság hatáskörébe tartozóan is létrehoztak ilyen tartalékot. Ezen tartalékokat a rendöri őrség vezénylésének a részeként a szolgálatszervezés során formálták, így abban mindig mások kerültek be. 1932-ig a kerületi osztály-parancsokságok által naponta vezényelt tartalékokból biztosítottak rendöröket a fökapitányságra karhatalmi szolgálat ellátása céljából, akiknek az elhelyezési körlete a Mosonyi utcai rendörlaktanya volt. ${ }^{33}$

A rendőröknek tisztának, ápoltnak kellett lenniük, öltözéküket és felszerelésüket a szolgálati utasításban foglaltaknak megfelelően kellett viselniük. Kötelesek voltak továbbá irattárcát is maguknál tartani. Komoly és előzékeny magatartást kellett tanúsítaniuk. Közlendőjüket udvarias módon, nyugodtan és egyértelműen kellett közölniük. Kerülniük kellett mindent, ami személyüket nevettség vagy gúny tárgyává tehette. A rendőröknek nem csupán a lakosságra, hanem a bajtársaikra is figyelmet kellett fordítaniuk. Ittas rendőrtársukat, vagy botrányt okozó rendőrt a társai kötelesek voltak a közönség szeme elöl haladéktalanul elvonni és az esetről jelentést tenni. Amennyiben a rendör azt tapasztalta, hogy valamelyik társa szabálytalanul járt el, akkor kötelessége volt arra figyelmeztetni, ha pedig annak nem volt foganatja jelentést kellett tennie az elöljárójának. A rendőröknek titokban kellett tartaniuk a hivatalos müködésük során tudomásukra jutott információkat, nyilvános helyen illetéktelen személyek által is hallható módon a szolgálatukkal összefüggő témákról nem beszélhettek. A szolgálatban lévő rendőröknek dohányozni, étkezni, a szolgálat ellátásán kívül eső tevékenységet végezni tilos volt. ${ }^{34}$

A rendőri őrszolgálatot teljesítőknek, azaz az őrszemeknek és a járőröknek szolgálati körzetüket kiválóan kellett ismerniük. Arcról fel kellett ismerniük a körzetükben lévő rovottmúltúakat, a kéjnőket, ismerniük kellett az utcaneveket, a közintézmények és nyilvános helyek a vasút-, hajó- és bérkocsiállomások elhelyezkedését, tüzjelző- és telefonállomások helyét, az orvosok, a szülésznők és a patikák címeit. A rendőr őrszemek egymással - a föparancsnok által parancsban meghatározott - hang- és látjelekkel tartottak kapcsolatot. Az örszemek a posztjukat általában nem hagyhatták el, ha azonban erre mégis sor került valamilyen intézkedésből fakadóan arról az őrszobájukat értesíteniük kellett. Az örszoba-parancsnoknak pedig kötelessége volt az örszobán tartózkodó rendörök közül az üresen maradt posztra rendőrt küldeni. ${ }^{35}$

A rendőri őrszemélyzet szolgálati teendőit a korabeli szabályzatok hármas csoportosításban tárgyalták. Ezek voltak a megfigyelö, a megelöző és a felfedezö jellegü tevékenységek. Ez a fajta felosztás pedig abból fakadt, hogy magától a rendőrségtől is ilyen hármas felosztású tevékenységet vártak el.

A megfigyelési teendöket a rendőri örség tagjainak a feladatai közé sorolták a rendőrséget érdeklö személyek, anyagok és tárgyak figyelemmel kísérése tekintetében. E személyek közé sorolták a rendőri felügyelet alá helyezetteket, a közveszélyeseket (rovott múltúakat), a koldusokat, a csavargókat, a házalókat, a kéj- és ledér nőket, a bérkocsi vállalatok alkalmazottait, a felügyelet nélküli iskolás gyermekeket, az ittasokat, az örülteket, a gyámoltalanokat (szellemi- és / vagy testi fogyatékosokat).

A rendőrséget érintő események alatt olyan természeti csapások előfordulását értették, amelyek veszélyt jelenthettek a személy- és vagyonbiztonságra, a közrendvédelemre. Ide sorolták a tüzvészt, az árvízt, a jégverést, s hófúvást, a sürü ködöt, a járványos és ragályos megbetegedéseket. Ezen eseményeket a rendőri örség tagjainak haladéktalanul jelenteniük kellett az elöljáróiknak.

A rendőrséget érdeklő tárgyak közé sorolták mindazokat, amelyek alkalmasak lehettek a közrend, a közlekedés megsértésére. Ide sorolták a közterületen elhelyezett és a forgalmat akadályozó, vagy nehezítő építési és egyéb anyagokat, illetve törmelékeket, jármüveket, címtáblákat, bolti ernyőket, nyilvános hirdetéseket, közszemlére kihelyezett könyveket, képeket stb. E körbe tartozónak tekintették továbbá azokat a tárgyakat is, amelyek rongálása a közrendet veszélyeztethette. Ide tartozónak tekintették például a szobrokat, vasúti vágányokat, az utcai világítás eszközeit, a telefon- és távírda huzalokat stb. 
A rendőri örség tagjainak a megelözési feladatkörébe tartozónak tekintették a törvények, rendeletek által tiltott cselekmények megakadályozását és feljelentését, a személy- és vagyonbiztonságot, általában a közrendet veszélyeztető cselekmények elhárítását, a balesetek megelőzését, a gyámoltalanok útba igazítását, esetleg elhelyezését stb.

A rendőri örség felfedezö szolgálatteljesitési teendői közé tartozott: a körözött, kitiltott, vagy szökésben lévők elfogása, a büntetőtörvénykönyvbe foglalt cselekmények elkövetőinek letartóztatása, illetve följelentése, a bünelkövetés nyomainak a megörzése, a kitett, eltévedt vagy talált tárgyak, állatok, gyerekek beszállítása, a szerencsétlenségek okozóinak a kinyomozása. ${ }^{36}$

A rendőri őrség tagjai számára cselekvési korlátokat is felállítottak, nevezetesen, hogy a megfigyelő, megelőző és felfedező szolgálat eredményes teljesítése érdekében milyen cselekmények foganatosítására voltak jogosultak. A rendőri ôrség tagjai szolgálatuk eredményes ellátása érdekében jogosultak voltak fegyverhasználatra, elővezetésre, bekísérésre, feljelentésre. Elövezetés alatt azt értették, hogy a rendőr személyazonosság megállapítása érdekében személyeket a rendőrhatóság hivatalába előállít. A bekisérés fogalomkörébe tartozott, amikor a rendőr saját kezdeményezésére a rendőri hatóság hivatalába kísért büntetendő cselekmény elkövetésével vádolható személyt. Elöljárói parancsára a rendőr köteles volt továbbá elfogásokat is foganatosítani. A rendörök ezen cselekményeik megvalósítása során — külön rendeletben szabályozott módon — bilincset is használhattak. Ugyancsak külön jogszabályokban rögzítették, hogy a rendör mely esetekben és milyen módon hatolhatott be magánlakásokba nyílt rendelkezés nélkül. ${ }^{37}$

Közfeladatot ellátó személy vasúti- vagy hajózási-, illetve bérkocsi vállalat szolgálatában lévő személyek elfogására csak azok főnökeinek értesítésével kerülhetett sor abban az esetben, ha a vállalat a helyettesítése tekintetében a szükséges intézkedéseket megtette, illetve a feljebbvalója kijelentette, hogy az előállításnak a vállalat müködtetése szempontjából akadálya nincs. ${ }^{38}$

Egyenruhát viselő katonát a rendőr csak akkor kísérhetett be, ha a katona személyazonossága más módon nem volt megállapítható, vagy ha a bekísérésre nagyobb botrány vagy veszély elhárítása miatt került sor, illetve ha a katona a rendőrnek tettleg ellenszegült, vagy fegyverével megtámadta, a későbbiek során ezt az elöírást úgy pontosították, hogy ebben az esetben is a legközelebbi laktanyából kellett katonai őrjárat segítségét kérni. A rendőr, katonát ellenszegülés esetében is csak akkor kísérhetett be, ha a katonának a körzetében való tartózkodása közvetlen veszéllyel járt. A körülményekhez képest azonban ilyen esetekben is törekedni kellett arra, hogy a katonát lehetöleg ne a rendőrségre, hanem laktanyába kísérjék. ${ }^{39}$

Az elővezetésnek és a bekísérésnek külön szabályai voltak. A rendőrnek az illető személyt elöször is fel kellett szólítania, hogy önként menjen vele. Ha ez nem valósult meg, akkor a felszólítását meg kellett ismételnie azzal a kiegészítéssel, hogy engedetlenség esetén kényszerítő eszközt fog alkalmazni. Bilincselésre tettleges ellenszegülés esetében kerülhetett sor, amikor a fegyverét is használhatta a rendőr, de csak a legnagyobb kímélettel. Fegyverhasználat esetén kötelező volt az azonnali segély nyújtása. ${ }^{40}$

A bekísérteknél támadásra alkalmas eszközt nem volt szabad hagyni, személymotozást azonban csak büntett esetében lehetett foganatosítani. A rendőrnek ügyelni kellett arra, hogy az elővezetett, vagy bekísért személy útközben semmit el ne dobjon, illetve át ne adjon, meg ne semmisítsen, továbbá senkivel se beszéljen, senkinek se adhasson jelet és semmit át ne vegyen. A rendőr köteles volt továbbá arra is ügyelni, hogy a személy meg ne szökjön, illetve önmagában kárt ne tegyen.

Összességében tehát a rendőri őrség tagjainak a város közbiztonsága felett kellett őrködniük a törvénytelen cselekedeteket megelőzniük és megakadályozniuk, mégpedig szabályozott módon. A rendőri őrség a fővárosi rendőrségnek nem csupán a legnagyobb, hanem egyben a hagyományos része is volt. A budapesti rendőrség müködésének másik pillérét a detektívtestület alkotta. ${ }^{41}$

A Budapesti Magyar Királyi Állami Rendőrség detektívtestületét 1885-ben hozták létre, müködését pedig 1886 elején kezdte el. A detektívtestületet megelőzően a detektívekhez hasonló szolgálatot az úgynevezett polgári biztosok végezték. Annak ellenére azonban, hogy volt közöttük néhány tehetséges, kiemelkedő eredményeket létrehozó személy is, összességében korruptak voltak, az alvilággal összefonódtak. A THAISZ Elek által vezetett fővárosi rendőrség átszervezése során, TÖRÖK János fökapitánnyá való kinevezését követően hozták létre az 50 fönyi polgári biztos helyébe a kezdetben 28 fös létszámmal müködő detektív testületet. A detektívtestület első szabályzata 1888. VII. 1-én lépett hatályba. Az új testület kiválóan beváltotta a hozzá füzött reményeket, mivel a fővárosi bűnügyek felderítésében döntő szerepre tett szert. A fővárosi rendőrség detektívtestületének a sikerét látva a vidéki nagyvárosok is egymás után hozták létre rendőrségeik detektívtestületeit. A Budapesti Magyar Királyi Állami Rendőrség detektívtestületének a létszáma is gyarapodott. 
Az első világháborút megelőzően már 165 fő teljesített szolgálatot a fővárosi rendőrség detektívtestületében. A háború után pedig a fővárosban már 400 fö́t tett ki a detektívtestület létszáma. A kommün bukása után pedig 500 föt számlált a fővárosi rendőrség detektívtestülete. ${ }^{42}$

A detektívtestület eredményességét nem csupán a testület erkölcsi állapota, a detektívek iskolázottsága biztosította, hanem a jogi és a technikai feltételek javulása is. Ide sorolható, hogy 1881ben külön törvény született a fővárosi rendörségre vonatkozóan. ${ }^{43}$ Ezt megelözően — 1880-ban életbe lépett büntetötörvénykönyv nyomán ${ }^{44}$ - 1880-ban a belügyminiszter rendeleti úton szabályozta a rendőri büntetőeljárást. ${ }^{45} \mathrm{~A}$ technikai feltételek javulása tekintetében pedig kiemelkedik az újlenyomat azonosítás bevezetése, Nagy Britannia után az európai kontinensen elsőként. A Bűnügyi Nyilvántartó Hivatal létrehozására 1903-ban került sor, amely 1906-tól országos jellegúvé vált, majd 1909. I. 1-től Országos Bünügyi Nyilvántartó Hivatal elnevezéssel müködött. Az 1908-ban létesített Bünügyi Múzeum, amelyben — az igazságügy- és a belügyminiszter közös rendelete értelmében - a tipikus és a speciális bünesetek bünjeleit őrizték és mutatták be oktatási célzattal, szintén hozzájárult a bűnüldöző szervek eredményes müködéséhez. ${ }^{46}$

A fővárosi rendőrség detektívtestülete a főkapitányi hivatal segédintézményeként müködött. A detektívtestület a fökapitány — távolléte esetén a helyettese — közvetlen felügyelete alá tartozott. A detektívtestület önállóan nyomozásba nem kezdhetett, csak ha a késedelem veszéllyel járhatott. A testület munkáját elsősorban a bünügyi osztály felhívásai nyomán teljesítette ugyan, azonban minden jelentősebb rendőri osztályhoz, illetve a kerületi kapitányságokhoz is vezényeltek detektíveket. A bünügyek adminisztrálása nem tartozott a detektívtestület feladatkörébe, így jegyzőkönyvet sem vehettek fel. A detektívek eljárásaik eredményeit jelentésbe foglalták. A detektívtestület sem bírósággal, sem közigazgatósági hatósággal nem levelezhetett, hozzájuk felhívással sem fordulhatott. ${ }^{47}$

A detektívek főnöke a detektívfelügyelő, majd a detektív főfelügyelő volt, aki a főkapitány közvetlen alárendeltségébe tartozott. A detektívfelügyelőt távollétében a detektív felügyelöhelyettes helyettesítette. A detektívtestülethez szükség szerint beosztottak segédfogalmazókat, írnokokat stb. A detektívtestületi tagok szakterületi csoportosításban teljesítettek szolgálatot. Így voltak többek között a zsebtolvajoknak, a szélhámosoknak stb. detektív csoportjai.

A detektívekre lényegében az őrszolgálati személyzettel szemben támasztott etikai elvárásokkal szinte azonos szabályok vonatkoztak. Még a viselkedési és az öltözködési követelmények is hasonlóak voltak azzal az eltéréssel, hogy a detektívek egyenruhát nem hordhattak, sőt nyilvános helyeken a rendőrtársuk és elöljáróik köszöntését is mellőzniük kellett. Abban az esetben pedig, ha álruhát viseltek, annak megfelelően kellett viselkedniük. ${ }^{48}$

A detektívek szolgálati feladatait a szolgálati utasításuk két fő csoportra osztotta, nevezetesen az általános és a különleges teendőkre. Az általános tevékenységeikhez azok a teendők tartoztak, amelyeket külön utasítás nélkül saját elhatározásból is teljesíteniük kellett. A különleges feladatok körébe tartozónak pedig azokat a tevékenységeket tekintették, amelyeket külön utasításba kaptak. E feladatok teljesítése érdekében megvalósított teendőiket is két csoportba osztották, a figyelési és az intézkedési teendőkre.

A figyelési teendők teljesítése kiterjedt: személyek, helységek, események és tárgyak megfigyelésére. A személyek tekintetében a testület érdeklödési körébe tartoztak a rendőri felügyelet alatt álló, a rovott múltúak, a csavargók, az életmódjuk alapján — költekezés, rejtőzködés, szokatlan életvitel — gyanús személyek, a rendzavarások felbujtói. E személyeknek különösen a kapcsolatait kellett felderíteni, illetve a feltételezhetően előkészítés alatt álló büncselekményekről voltak kötelesek a detektívek haladéktalanul jelentést tenni.

A helységeket illetően a detektívek megfigyelő munkáját elsősorban szállodák, vendéglők kávéházak, mulatóhelyek, tánctermek, zálogházak, tömeglakások, gyárak, malmok és piacok térségére koncentrálták. A detektíveknek a körzetükbe tartozó helységeket gyakran meg kellett látogatniuk, a szállodákban a névjegyzékeket naponta ellenőrizniük, a többi helységekben pedig a közönséget, illetve a vendégeket meg kellett figyelniük oly módon, hogy bármikor naprakész jelentést tehessenek.

Az események tekintetében a detektíveknek a rendőrséget érdeklö ünnepségek, csoportosulások, rendezvények, munka beszüntetések, balesetek és katasztrófák helyszínén jelen kellett lenniük.

A rendőrséget érdeklő tárgyak körébe tartozónak tekintették a detektíveket illetően a bünelkövetésre alkalmas eszközök felbukkanását, a felügyelet nélkül hagyott árúkat és kulcsokat, valamint robbanóanyagokat. Ezen tárgyakkal, illetve helyzetekkel a detektíveknek foglalkozniuk kellett, azokról jelentést kellett készíteniük. ${ }^{49}$ 
A detektívek feladatainak másik körét az intézkedési teendők alkották. A detektíveknek általában a legközelebbi egyenruhás rendőr figyelmét kellett felhívni a rendbontó cselekedetekre. Személyesen csak akkor volt köteles fellépni a detektív, ha elérhető távolságban egyenruhás rendőr nem tartózkodott és a késedelem személy- és vagyonbiztonság jelentős károsodásával járhatott, illetve a közrend és közbiztonság jelentős megzavarását eredményezhette. Kötelesek voltak a detektívek továbbá akkor is közbelépni, ha az egyenruhás rendör támogatásra, vagy segítségre szorult.

A körözött személyeket a detektívek minden körülmény között kötelesek voltak elfogni. A jelentősebb büncselekmények — gyilkosság, rablás, pénzhamisítás stb. — helyszínének biztosításáról gondoskodniuk kellett mindaddig, amíg az egyenruhás rendőrök a helyszínre érkeztek. Büncselekményen való tettenérés esetén a tettest el kellett fogniuk.

A detektívek különleges utasításra végzett teendőit is két csoportra osztották a rendes teendőkre és a rendkívüliekre. A rendes teendők közé tartozott a helyszíni szemlén való részvétel, a személyek életviszonyainak a kipuhatolása, a személyek és tárgyak kipuhatolása, a motozás, a házkutatás, az üldözés és az elfogás.

A detektíveknek kötelességük volt a büncselekmény miatt körözött (nyomozólevéllel keresett) személyeket elfogni, vagy ha az elfogás késedelemmel, veszéllyel járhatott akkor üldözni az ország határáig. A Magyar Királyi Állami Rendőrség létrehozását megelőzően azonban a Budapest határán kívüli üldözés — szállás, útiköltség és napidíj — költségeit abban az esetben térítette meg a főváros, ha az üldözéshez a detektív fönöke a beleegyezését adta. Budapest határán kívüli üldözés kezdetén a detektíveknek ezért borítékban küldött levél formájában jelenteniük kellett a tartózkodási helyüket, az üldözött személyt, majd az üldözés fejleményeit naponta távirati értesítés formájában.

A detektíveknek kötelességük volt a személyesen végrehajtott elfogásokat diszkréten megvalósítani. Amennyiben lehetőségük nyílt az elfogást megelőzően a célszemélyt ki kellett kérdezniük. A kikérdezés a személyazonosság megállapítására irányult elsősorban. A kikérdezés tartalma nem terjeszkedhetett az illető terhére rótt büncselekmény terhére.

Igazoltatás előtt a detektíveknek kellett igazolványuk felmutatásával igazolniuk magukat, mivel csak ez esetben voltak jogosultak az igazoltatás végrehajtására.

Amennyiben a detektív az elfogás helyszínén olyan személyeket is észlelt, akikről feltételezhető volt a büncselekmény elkövetésében való részvétel, akkor őket is el kellett fogniuk. ${ }^{\mathbf{5 0}}$

A detektívek a feladataikat a detektívfelügyelő által havonta készített szolgálati beosztásban foglaltak szerint látták el. A detektívek csak azon ügyekben járhattak el, amelyekre megbízást kaptak. A detektívek szolgálattételre három helyre voltak kirendelhetőek:

- a központi bünügyi osztályhoz, ahol az osztályvezető osztotta be a detektíveket a rendőrtisztviselők mellé;

- a kerületi kapitányságokhoz;

- és a felügyeleti szolgálatot ellátó tisztviselők mellé.

E helyeken a detektívek szolgálatteljesítési nemei voltak a felügyeleti szolgálat a tartalékszolgálat, a vasúti szolgálat, hosszú- és rövid portyaszolgálatok, valamint az éjjeli szolgálat, majd pedig a nyomozószolgálat. ${ }^{51}$

A központi felügyeleti szolgálat reggel kilenc órakor kezdődött, amikor a detektívek jelentették az előző napi teendőiket, illetve a letartóztatottakkal kapcsolatos jelentéseket is végig hallgatták. Ily módon a bünügyi helyzetről naprakész ismeretek birtokába kerültek. Ezen időszak délelőtt 11 óráig tartott, amikor rövid időt igénylő teendőket kellett végezniük a detektívszobákban. Délelőtt 11 órától délután 14 óráig szabadok voltak, majd jelentkezniük kellett a központi felügyeletet tartó rendörtisztviselőnél, akinek az intenciói szerint tevékenykedtek másnap reggel nyolc óráig a szolgálatuk lejártáig, illetve addig, ameddig a felmerült ügyekben a gyors intézkedést be nem fejezték. A központi felügyeleti szolgálatot ellátó detektívek szolgálati idejük alatt a fökapitány, a bünügyi osztály vezetője, a központi felügyeletet ellátó tisztviselö, illetve a detektívfelügyelő engedélye nélkül a fökapitányi épületet nem hagyhatták el. A felügyeleti szolgálat végén a detektívek jelentést tettek a szolgálati idejük alatt végrehajtott feladataikról. Ezen már részt vettek a következő napra központi felügyeleti szolgálatra beosztott detektívek is. ${ }^{52}$

Tartalékszolgálat ellátására a központi felügyeleti szolgálatot követő 24 órában került sor. Ennek kezdetén a detektívek a reggeli jelentésük leadását követően délig szabadok voltak, majd délután 18 óráig nyáron az uszodákat voltak kötelesek látogatni, más évszakokban pedig az esetenként kijelölt kerületekben portyaszolgálatot kellett teljesíteniük. Este 18 órától 21 óráig a detektívszobában kellett tartózkodniuk és a fơkapitány vagy a bünügyi osztály vezetőjének a rendelkezésére áll- 
niuk. 21 órától — ha más feladatot nem kaptak — a lakásukra távozhattak, amelyet másnap hajnali öt óráig nem hagyhattak el, hogy szükség esetén szolgálattételre behívhatóak legyenek. ${ }^{53}$

A vasúti szolgálat napján a tevékenység végzésére kirendelt detektívek kötelesek voltak az öszszes vasút érkezésének és indulásának az időpontjában az állomáson tartózkodni, az utasokat szemmel tartani, a körözött személyeket és a fővárosból kitiltottakat elfogni, a vonatok mozgása közötti időszakban pedig a várócsarnokban a tolvajokat és rendbontókat elfogni. Amennyiben a pályaudvarra érkező vonatról távirat érkezett a pályaudvarra arról, hogy a vonaton lopás, vagy más büncselekmény történt, akkor a vasúti szolgálatra kirendelt detektívnek az első ellenvonattal a legközelebbi állomásra kellett utaznia, ahol elfoghatta a tolvajt, mivel azok általában még a fővárosba érkezés előtt leszálltak a vonatról. Azon a vonaton pedig, ahol a lopás történt - a pályaudvarig való utazás során - a lopás körülményeit kellett a detektíveknek megállapítaniuk. A pályaudvaron szolgálatot teljesító detektívek számára egy-egy könyvet helyeztek el, amelybe a detektívek bejegyezték a szolgálati idejük során tett intézkedéseket, mikor, hol és miért fogtak el személyeket, illetve milyen lopások történtek stb. ${ }^{54}$

A portyaszolgálat során a detektívek végigjárták a számukra kijelölt területet, elsősorban a forgalmas közterületeket, illetve az elhagyott mellékutakat. Ennek során a nyilvános helyeket — kávéházakat, korcsmákat, piacokat, uszodákat, éttermeket — is meglátogatták, ahol az általuk ismert bünözőket igazoltatták vagy szükség szerint elöállították. ${ }^{55}$

A detektív személyzet ellátáshoz kapcsolódó teendök közül az egyik legfontosabb a napi jelentés volt, melytől csak abban az esetben tekintettek el, ha a jelentéstétel a folyamatban lévő nyomozást veszélyeztette. A detektíveknek az iratait, feljegyzéseit a detektívszobában személyre szóló zárható fiókban kellett tartani. A detektívek a jelentéseiket itt írhatták meg. A detektívteremben hangoskodni tilos volt. A detektíveknek a detektívszobán kívül tartózkodni csak addig és ott volt szabad, amíg és ahol a szolgálati feladatai ellátásához az szükséges volt. A detektívszobában volt kifüggesztve a detektívek szolgálati szervezése. A rendőrségi nyilvántartások a detektívek számára a nap bármely szakában azonnal a rendelkezésükre álltak. Az álöltözékeket a detektívek csak a detektívfelügyelő engedélyével használhatták. A detektíveknek minden megbízatásukat, amit nem a detektívfelügyelötől kaptak a lehető legrövidebb időn belül jelenteniük kellett a detektívfelügyelőnek. A detektívszoba számára egy könyvet rendszeresítettek, amelybe a detektívek naponta kötelesek voltak bejegyezni az általuk elfogottak személyi adatait, valamint az elfogás helyét és idejét továbbá az okát. ${ }^{\mathbf{5 6}}$

A nyomozások során felmerült költségekröl a detektíveknek jegyzéket kellett készíteni és a nyomozás végén azt a detektívfelügyelőnek átadni, aki azt belátása szerint elfogadta vagy elutasította, illetve helyesbítette, majd érvényesítési záradékkal való ellátása nyomán minden hó elején a fökapitányhoz felterjesztette. Ennek alapján utalványozta ki a főkapitány a detektívek számára az igényelt összeget. ${ }^{57}$

Ezek a szolgálati teendők nem helyettesítették „A nyomozó rendőri hatóságok és közegek számára" címü 1899-ben a belügyminiszter által kibocsájtott rendeletet. ${ }^{\mathbf{5 8}}$

A magyar rendőrségek államosításával ${ }^{59}$ a Budapesti Magyar Királyi Állami Rendőrség szabályzóit tekintették ugyan kiindulási alapnak, azonban a városok tekintetében immár az országos rendőri szervezet, azaz a Magyar Királyi Állami Rendőrség számára új szabályzatokat hoztak létre. Ezek a szabályzatok ugyan jelentős mértékben hasonlítottak a fővárosi rendőrség számára korábban létrehozott szabályozásokra, azonban mégsem voltak ugyanazok. A Magyar Királyi Állami Rendőrség ügyintézöi hatáskörére vonatkozóan a belügyminiszter $1919-$ ben $^{60}$, majd a testület szervezetének és szolgálatának a szabályozására 1921-ben ${ }^{61}$ bocsájtott ki rendeleteket. Ezt követte a rendörségre vonatkozó 1922. évi törvény ${ }^{62}$, majd annak végrehajtásáról szóló ugyancsak 1922-ben kiadott belügyminiszteri rendelet. ${ }^{63}$

Összességében tehát megállapítható, hogy a fővárosi rendőrség személyi állományának a tevékenységét a kor színvonalát tükröző, több szabályzatot magába foglaló szabályozási rendszer határozta meg. Ez a rendszer több évtized tapasztalatait foglalta magába, ily módon - mint a legalkalmasabb szabályzórendszer - a városi rendőrségek államosítása nyomán a Magyar Királyi Állami Rendőrség szabályzatainak is az alapjává vált.

Ezek a szabályzatok tükrözték, hogy a testület tagjaival szemben az állam jelentős erkölcsi színvonalat tükröző tevékenységet igényel, illetve a személyi állomány hathatós kihasználására irányuló szervezési gyakorlatot valósít meg. Egyértelműen kitűnik a szabályzatokból az is, hogy a fövárosi rendőrség a lakosságot nem ellenfélnek, hanem a magyar nemzet azon részének tekintette, amelynek az érdekében müködik a testület. 
A polgári magyar állam időszakában a magyar rendvédelem két fő pillértestületen, a csendőrségen és a rendörségen nyugodott. Mindkét testület kiváló bünüldözési eredményeket ért el. A nyomozómunka kezelését azonban másképp közelítették meg a rendörségnél és a csendörségnél. A testületen belüli detektív szolgálati ág létrehozása a rendőrséget jellemezte. Míg a csendőrségnél a nyomozó munkát is az őrsökön szolgálatot teljesítő csendörök végezte. A csendőrségnél „csupán” a nyomozó munka háttér tevékenységei — bünügyi labor, csendőr nyomozó parancsnokság, stb. számára hoztak létre a testület megszokott szervezeti felépítésétől eltérő szervezeti elemeket. ${ }^{64}$

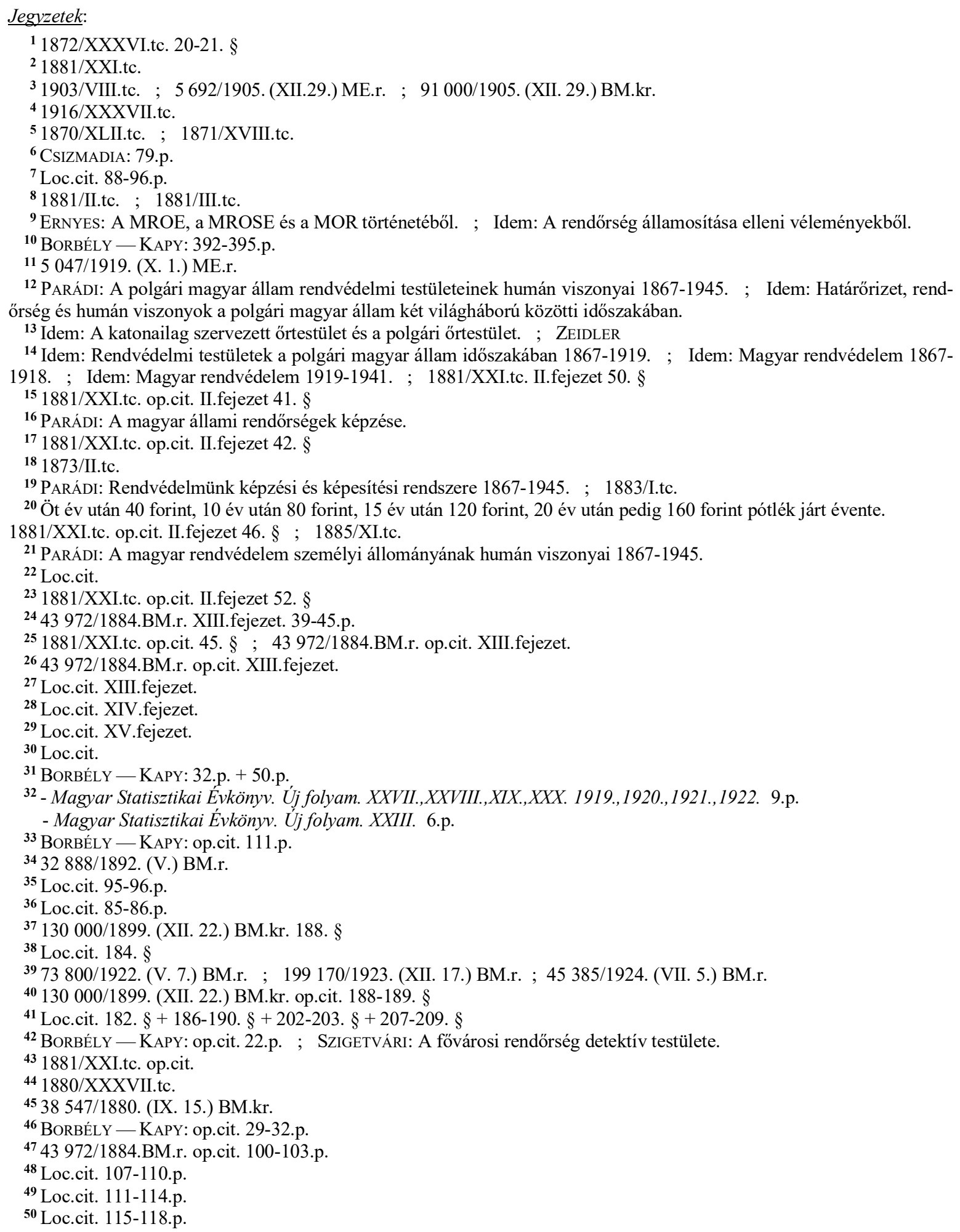


${ }^{51}$ Loc.cit. 124-125.p.

52 Loc.cit. 125.p.

${ }^{53}$ Loc.cit. 126.p.

${ }^{54}$ Loc.cit. 127.p.

${ }^{55}$ Loc.cit. 128.p.

${ }^{56}$ Loc.cit. 129.p.

${ }^{57}$ Loc.cit.

58130 000/1899. (XII. 22.) BM.kr. op.cit.

$595047 / 1919$. (X. 1.) ME.r.

6090 089/1919. (XII. 31.) BM.r.

${ }^{61} 39$ 820/1921. (1922. IV. 11.) BM.r.

62 1922/VII.tc.

${ }^{63} 102$ 837/1922. (VII. 28.) BM.r.

${ }^{64}$ SzIGETVÁRI: A Magyar Királyi Csendőrség nyomozó alakulatai. 99-113.p.

Forrás- és irodalomjegyzék (a jegyzetekben alkalmazott röviditések oldása):

\section{MONOGRÁFIÁK KISMONOGRÁFIÁK ÉS HASONLÓ JELLEGÜ KÖTETEK}

BORBÉLY - KAPY

$(10 . ; 31 . ; 33 . ; 42 . ; 46 . ;)$

CSIZMADiA

$(6 . ; 7 . ;)$

\section{TANULMÁNYOK}

ZEIDLER

$(13 . ;)$

ERNYES: A MROE, a MROSE és a MOR történetéből.

$(9 . ;)$

ERNYES: A rendőrség államosítása elleni véleményekböl.

(9.;)

PARÁDI: Rendvédelmünk képzési és képesítési rendszere 1867-1945.

(19.;)
BORBÉLY Zoltán — KAPY Rezső: (szerk.): A 60 éves magyar rendörség 1881-1941. Budapest, 1942, Halász Irodalmi és Könyvkiadó Vállalat. I.köt. 1-299 p. II.köt. 300-600 p.

- Csizmadia Andor: A magyar közigazgatás fejlödése a XVIII. századtól a tanácsrendszer létrejöttéig. Budapest, 1976, Akadémia Kiadó. 560 p. HUISBN 9630507137.

- ZEIDLER Sándor: A magyar rendőri rangok fejlődéstörténete a kiegyezéstől az ezredfordulóig. Rendvédelem-történeti Füzetek (Acta Historiae Praesidii Ordinis), XIV. évf. (2008) 17. sz. 116-137.p. HU-ISSN 1216-6774. A tanulmány korábbi változata 2003. november 12.-én, Budapesten hangzott el a Szemere Bertalan Magyar Rendvédelem-történeti Tudományos Társaság által szervezett rendvédelem-történeti tudományos konferenciasorozatnak „A rendvédelem humán viszonyai” címü XVII. konferenciáján. A publikált tanulmány az előadás javított, bővített és átdolgozott változta.

ERNYES Mihály: A MROE, a MROSE és a MOR történetéből. Rendvédelem-történeti Füzetek (Acta Historiae Praesidii Ordinis), XXIX.évf. (2019) 58.sz. 29-64.p. HU-ISSN 1216-6774. A tanulmány korábbi változata 2019. szeptember 26-án, Budapesten hangzott el a Szemere Bertalan Magyar Rendvédelem-történeti Tudományos Társaság által szervezett magyar rendvédelem-történeti tudományos konferencia-sorozatnak a „,100 éve államositották a magyar rendörségeket." címü XXXIV. rendezvényén. A publikált tanulmány az előadás javított, bővített és átdolgozott változata.

ERNYES Mihály: A rendőrség államosítása elleni véleményekből. Rendvédelem-történeti Füzetek (Acta Historiae Praesidii Ordinis), XXIX.évf. (2019) 58.sz. 15-28.p. HU-ISSN 1216-6774. A tanulmány korábbi változata 2019. szeptember 26-án, Budapesten hangzott el a Szemere Bertalan Magyar Rendvédelem-történeti Tudományos Társaság által szervezett magyar rendvédelem-történeti tudományos konferencia-sorozatnak a „100 éve államositották a magyar rendörségeket." címü XXXIV. rendezvényén. A publikált tanulmány az előadás javított, bővített és átdolgozott változata.

PARÁDI József: Rendvédelmünk képzési és képesítési rendszere 18671945. Rendvédelem-történeti Füzetek (Acta Historiae Praesidii Ordinis), XIII.évf. (2007) 16.sz. 90-93.p. HU-ISSN 1216-6774. A tanulmány korábbi változata 2002. november 12-én Budapesten hangzott el, a Szemere Bertalan Magyar Rendvédelem-történeti Tudományos Társaság által szervezett rendvédelem-történeti tudományos konferencia-sorozatnak , $A$ rendvédelmi szakképzés története” címü XVI. konferenciáján. A publikált tanulmány az előadás javított, bővített és átdolgozott változata. 
PARÁDI: A magyar rendvédelem személyi állományának humán viszonyai 1867-1945.

$(21 . ; 22 . ;)$

PARÁDI: A polgári magyar állam rendvédelmi testületeinek humán viszonyai 1867-1945.

(12.;)

PARÁDI: Rendvédelmi testületek a polgári magyar állam időszakában 18671919.

(14.;)

PARÁDI: Határőrizet, rendőrség és humán viszonyok a polgári magyar állam két világháború közötti időszakában.

(12.;)

PARÁDI: A katonailag szervezett őrtestület és a polgári örtestület.

(13.;)

PARÁDI: Magyar rendvédelem 18671918.

(14.;)

PARÁDI: Magyar rendvédelem 19191941.

(14.;)

PARÁDI: A magyar állami rendőrségek képzése.

(16.;)

SZIGETVÁRI: A fővárosi rendőrség detektív testülete.

(42.;)

SZIGETVÁRI: A Magyar Királyi Csendörség nyomozó alakulatai. (64.;)

\section{ADATTÁRAK}

Magyar Statisztikai Évkönyv. Új folyam. XXVII., XXVIII.,XIX.,XXX. 1919., 1920.,1921., 1922

(32.;)

Magyar Statisztikai Évkönyv. Új fo- lyam. XXIII.

(32.;)

\section{JOGSZABÁLYOK}

1870/XLII.tc.

(5.;)

1871/XVIII.tc.

(5.;)
PARÁDI József: A magyar rendvédelem személyi állományának humán viszonyai 1867-1945. Rendvédelem-történeti Füzetek (Acta Historiae Praesidii Ordinis), XIV.évf. (2008) 17.sz. 57-87.p. HU-ISSN 1216-6774. A tanulmány korábbi változata 2003. november 11-én, Budapesten hangzott el a Szemere Bertalan Magyar Rendvédelem-történeti Tudományos Társaság által szervezett rendvédelem-történeti tudományos konferencia-sorozatnak. „A rendvédelem humán viszonyai” című XVII. konferenciáján. A publikált tanulmány az előadás javított, bővített és átdolgozott változata.

PARÁDI József: A polgári magyar állam rendvédelmi testületeinek humán viszonyai 1867-1945. Rendvédelem-történeti Füzetek (Acta Historiae Praesidii Ordinis), XIX. évf. (2010) 22. sz. 92-114. p. A tanulmány korábbi változata 2008. október 10.-én Budapesten hangzott el, a Szemere Bertalan Magyar Rendvédelem-történeti Tudományos Társaság által szervezett rendvédelem-történeti tudományos konferenciasorozatnak „Másfél évszázad rendszerváltozásainak hatásai a nemzeti rendvédelmünkre" címü XXII. konferenciáján. A publikált tanulmány az előadás javított, bővített és átdolgozott változata.

PARÁDI József: Rendvédelmi testületek a polgári magyar állam időszakában 1867-1919. Rendvédelem-történeti Füzetek (Acta Historiae Praesidii Ordinis), XXIII. évf. (2013) 31-32-33-34.sz. 121-146.p. HU-ISSN 1216-6774. A tanulmány korábbi változata 2014. február 21-én, Budapesten hangzott el, a Szemere Bertalan Magyar Rendvédelem-történeti Tudományos Társaság által szervezett rendvédelem-történeti tudományos szimpozionsorozatnak ,, A kivételes hatalom és a közbiztonság” címü XIV. szimpozionján. A publikált tanulmány az előadás javított, bővített és átdolgozott változata.

PARÁDI József: Határőrizet, rendőrség és humán viszonyok a polgári magyar állam két világháború közötti időszakában. Rendvédelem-történeti Füzetek (Acta Historiae Praesidii Ordinis), XXIV.évf. (2014) 39-40-4142.sz. 99-118.p. HU-ISSN 1216-6774.

PARÁDI József: A katonailag szervezett őrtestület és a polgári őrtestület. Rendvédelem-történeti Füzetek (Acta Historiae Praesidii Ordinis), XXV.évf. (2015) 43-44-45-46.sz. 77-84.p. HU-ISSN 1216-6774.

PARÁDI József: Magyar rendvédelem 1867-1918. Rendvédelem-történeti Füzetek (Acta Historiae Praesidii Ordinis), XVII.évf. (2017) 53.sz. 3352.p. HU-ISSN 1216-6774.

PARÁDI József: Magyar rendvédelem 1919-1941. Rendvédelem-történeti Füzetek (Acta Historiae Praesidii Ordinis), XXVII.évf. (2017) 54.sz. 5992.p. HU-ISSN 1216-6774.

PARÁDI Ákos: A magyar állami rendőrségek képzése. Rendvédelemtörténeti Füzetek (Acta Historiae Praesidii Ordinis), XXIX.évf. (2019) 58.sz. 129-162.p. HU-ISSN 1216-6774.

SZIGETVÁRI Oszkár: A fővárosi rendőrség detektív testülete. Rendvédelem-történeti Füzetek (Acta Historiae Praesidii Ordinis), XXVII.évf. (2017) 53.sz. 85-96.p. HU-ISSN 1216-6774.

SzIGETVÁRI Oszkár: A Magyar Királyi Csendőrség nyomozó alakulatai. 99-126.p. In PARÁDI József — SZAKÁLY Sándor — SZIGETVÁRI Oszkár — ZÉTÉNYI Zsolt: Nyomozati utasitások a Magyar Királyi Csendörség számára. Budapest, 2018, Szemere Bertalan Magyar Rendvédelem-történeti Tudományos Társaság. 401 p. HU-ISBN 978615803094 6. /A magyar rendvédelem-történet hagyatéka, 2./ HU-ISSN 2064-4728.

Magyar Statisztikai Évkönyv. Új folyam. XXVII.,XXVIII.,XIX.,XXX. 1919.,1920.,1921.,1922. Budapest, 1925, Magyar Királyi Statisztikai Hivatal. $277 \mathrm{p}$.

Magyar Statisztikai Évkönyv. Új folyam. XXIII. Budapest, 1915, Magyar Királyi Statisztikai Hivatal. 880 p.

1870/XLII.tc. a köztörvényhatóságok rendezéséról.

1871/XVIII.tc. a községek rendezéséről. 
1872/XXXVI.tc.

(1.;)

$1873 /$ II.tc.

(18.;)

1880/XXXVII.tc.

(44.;)

$1881 /$ II.tc

(8.;)

1881/III.tc.

(8.;)

1881/XXI.tc.

$(2 . ; 14 . ; 15 . ; 17 . ; 20 . ; 23 . ; 25 . ; 43 . ;)$

1883/I.tc.

(19.;)

1885/XI.tc.

(20.;)

1903/VIII.tc.

(3.;)

1916/XXXVII.tc.

(4.;)

1922/VII.tc.

(62.;)

38 547/1880. (IX. 15.) BM.kr. (45.;)

43 972/1884.BM.r.

(24.;25.;26.;27.;28.;29.;30.;47.;48.; 49.;50.;51.;52.;53.;54.;55.;56.;57.,)

32 888/1892. (V.) BM.r (34.;35.;36.;)

130 000/1899. (XII. 22.) BM.kr. (37.;38.;40.;41.;58.;)

5 692/1905. (XII.29.) ME.r.

(3.;)

91 000/1905. (XII. 29.) BM.kr. (3.;)

5 047/1919. (X. 1.) ME.r.

(11.;59.;)

90 089/1919. (XII. 31.) BM.r. (60.;)

39 820/1921. (1922. IV. 11.) BM.r. (61.;)

73 800/1922. (V. 7.) BM.r. (39.;)
1872/XXXVI.tc. Buda-Pest fővárosi törvényhatóság alakításáról és rendezéséről.

1873/II.tc. a kiszolgált altisztek alkalmazásáról.

- 1880/XXXVII.tc. a magyar büntetötörvénykönyvek (1878/V.tc. és 1878/XI.tc.) életbe léptetéséröl.

— 1881/II.tc. a csendőrség legénységi állományának a kiegészítéséröl.

— 1881/III.tc. a közbiztonsági szolgálat szervezéséről.

— 1881/XXI.tc. a Budapest-fővárosi rendőrségről.

— 1883/I.tc. a köztisztviselők minősítéséről.

— 1885/XI.tc. az állami tisztviselők, altisztek és szolgák nyugdíjazásáról.

- 1903/VIII.tc. a határrendörségröl.

— 1916/XXXVII.tc. a Fiumei Magyar Királyi Állami Rendőrségről.

- 1922/VII.tc. a Magyar Királyi Állami Rendőrség és a Magyar Királyi Csendőrség létszámának, kiegészitési módjának és felfegyverzésének megállapításáról.

— $\quad 38$ 547/1880. (IX. 15.) BM.kr. a magyar büntető-törvénykönyvek végrehajtása tárgyában. Magyarországi Rendeletek Tára, XIV.évf. (1880) I.füzet 629-659.p.

— 43 972/1884.BM.r. a fővárosi rendőrség számára kiadott Utasítás tárgyában.

NÉMETHY Tihamér - TÖRÖK Lajos: Rendöri vonatkozású törvények, rendeletek és eljárási szabályok gyüjteménye. 100-131.p. Budapest, 1926, Editor. 822 p. /Rendörtisztviselök zsebkönyvtára./

- 32 888/1892. (V.) BM.r. a rendőri őrség rendeltetése és hatásköre, szervezeti szabályzata és általános szolgálati utasítása.

NÉMETHY Tihamér - TÖRÖK Lajos: Rendöri vonatkozású törvények, rendeletek és eljárási szabályok gyüjteménye. 50-99.p. Budapest, 1926, Editor. 822 p. /Rendörtiszt-viselők zsebkönyvtára./

- $\quad 130$ 000/1899. (XII. 22.) BM.kr. a bünvádi perrendtartásról szóló 1896/XXXIII.tc. életbe léptetése alkalmából a nyomozó rendőri hatóságok és közegek részére kibocsátott Utasítás tárgyában. Magyarországi Rendeletek Tára, XXXIII.évf. (1899) II.füzet. 2416-2417.

— 5692/1905. (XII.29.) ME.r. a határrendőrségről szóló 1903/VIII.tc. életbe léptetéséröl. Magyarországi rendeletek Tára, XXXIX.évf. (1905) I.füzet. 1455.p.

- 91 000/1905. (XII. 29.) BM.kr. valamennyi törvényhatósághoz Fiume város kivételével a határrendőrségről szóló 1903/VIII.tc. életbe léptetésének a végrehajtásáról.

Magyarországi rendeletek Tára, XXXIX.évf. (1905) I.füzet. 1455-1541.p.

- 5 047/1919. (X. 1.) ME.r. a rendőrség államosításáról. Magyarországi Rendeletek Tára, LIII.évf. (1919) I.füzet. 752-767.p.

— 90 089/1919. (XII. 31.) BM.r. az állami rendőrség ügyintéző hatásköréröl. Magyarországi Rendeletek Tára, LIII.évf. (1919) I.kötet. 1092-1096.p.

- 39 820/1921. (1922. IV. 11.) BM.r. a Magyar Királyi Állami Rendőrség szervezetének és szolgálatának szabályozása. Budapesti Közlöny, LVI.év. (1922) 89.sz. 1-9.p.

- $\quad 73$ 800/1922. (V. 7.) BM.r. a Magyar Királyi Honvédség egyéneivel szemben követendő rendőri eljárás szabályozása.

NÉMETHY Tihamér - TÖRÖK Lajos: Rendöri vonatkozású törvények, rendeletek és eljárási szabályok gyüjteménye. 494-500.p. Budapest, 1926, Editor. 822 p. /Rendőrtisztviselők zsebkönyvtára./ 
102 837/1922. (VII. 28.) BM.r. (63.;)

199 170/1923. (XII. 17.) BM.r. (39.;)

45 385/1924. (VII. 5.) BM.r. (39.;)
102 837/1922. (VII. 28.) BM.r. az 1922/VII.tc.-nek a Magyar Királyi Állami Rendőrségre vonatkozó rendelkezései végrehajtása. 282-288.p. - Belügyi Közlöny, XXVII.évf. (1922) 31.sz. 1365-1374.p.

- NÉMETHY Tihamér - TÖRÖK Lajos (szerk.): Rendöri vonatkozású törvények, rendeletek és eljárási szabályok gyüjteménye. Budapest, 1926, Editor Kiadó. 282-288.p.

- 199 170/1923. (XII. 17.) BM.r. fegyveres testületek egyéneivel szemben követendő rendőri eljárás.

NÉMETHY Tihamér - TÖRÖK Lajos: Rendöri vonatkozású törvények, rendeletek és eljárási szabályok gyüjteménye. 500-501.p. Budapest, 1926, Editor. 822 p. /Rendőrtisztviselők zsebkönyvtára./

— 45 385/1924. (VII. 5.) BM.r. folyamőrség egyéneivel szemben követendő eljárás.

NÉMETHY Tihamér — TÖRÖK Lajos: Rendöri vonatkozású törvények, rendeletek és eljárási szabályok gyüjteménye. 501-502.p. Budapest, 1926, Editor. 822 p. /Rendőrtisztviselők zsebkönyvtára./ 